OPEN ACCESS

\section{Harnessing universal motivators to enable a humanitarian response to climate change}

To cite this article: Judith Ford 2009 IOP Conf. Ser.: Earth Environ. Sci. 6572012

View the article online for updates and enhancements.
You may also like

$$
\begin{aligned}
& \text { - Harnessing biological energy } \\
& \text { O Z Roy } \\
& \text { - Small-Signal Stability Analysis of The } \\
& \text { Hydrokinetic Energy Harnessing } \\
& \text { Connected to The Grid } \\
& \text { W I lbrahim, M R Mohamed and R M T R } \\
& \text { Ismail } \\
& \text { - Buckling-induced smart applications: } \\
& \text { recent advances and trends } \\
& \text { Nan Hu and Rigoberto Burgueño }
\end{aligned}
$$

The Electrochemical Society

Advancing solid state selectrochemical sceence S tectinology

243rd Meeting with SOFC-XVIII

Boston, MA • May 28 - June 2, 2023

Accelerate scientific discovery!
Learn More \& Register

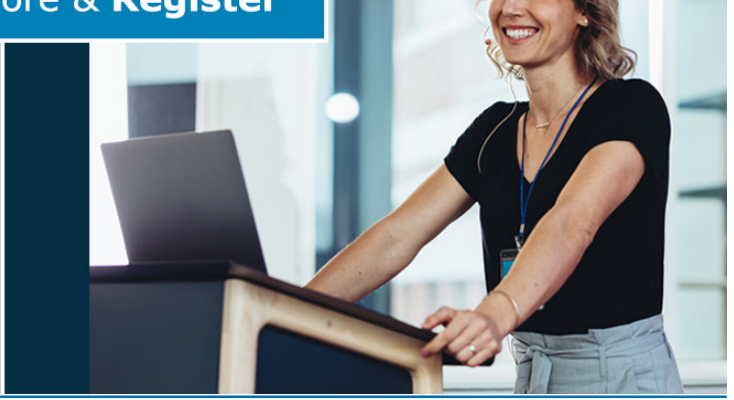

This content was downloaded from IP address 3.85 .5 .30 on $26 / 04 / 2023$ at $10: 12$ 


\section{Harnessing universal motivators to enable a humanitarian response to climate change} Judith Ford University of Amsterdam, Department of Social \& Behavioral Sciences, Amsterdam, The Netherlands

Until the industrialization of North America, Europe, and Oceania (e.g., Western Industrialized Nations, herein 'WIN') more than a century ago, humankind around the globe lived primarily in agrarian societies directly affected by climate. In North America particularly, towns and fields were seen as surrounded by a larger and savage nature (McKibben), and hymns and prayers related to weather (Sleeth). As WIN populations became more urban, nature became both revered from afar as 'wilderness' and something to be conquered and corralled by man (Hays). However, these societies remained aware of industrialization's negative impact on nature, as embodied in a constantly shifting stream of symbolic, discoursive 'emblems', such as deforestation, smog, and acid rain (Hajer).

The current emblem is human-accelerated (anthropogenic) climate change. Charles Tilly asserts that dramatic changes, such as the severe weather experienced in nearly every corner of the world, force people of diverse backgrounds to find collective reasons "to the question of "why?". Through the search for a common explanation, climate change has become one of the "great narratives in global society" (Neverla). During the summer of 2007, the year credited as the tipping point of public awareness, a BBC (2007) World Service Poll found: "79\%...(of citizens from)...twenty-one countries, (including many of the twenty top carbon emitters (Marland et al.) and most of the fifteen nations invited to the subsequent Major Economies Meetings on Energy Security and Climate Change)...say that human activity, including industry and transportation, is a significant cause of climate change...(only in India do less than half agree that)...(and 90\%) say that action is necessary to address global warming". But why has climate change has captured and held more public attention in WIN societies than prior emblems and provoked broader discussions on economic and social justice, larger environmental degradation, and even the validity of globalization and neo-liberal policy (Hawken)?

1. Although WIN disproportionately contribute(d) to climate change, and less industrialized nations will be more deeply affected, the transnational nature of anthropogenic climate change affects all humans in an unpredictable manner, primarily through the effects of extreme weather and resultant conflicts wrought by scarcities of water, arid land, and other natural resources.

2. Secondly, climate catastrophe (i.e., the world ending in flames, floods, and ice) is a common theme throughout mythology (e.g. Christians' Revelations and Noah's floods; Nordic Fimbulwinter) (Weart). Climate catastrophe is seen a punishment for irresponsible human behavior.

This combination of unpredictability and ages-old prophesy has coalesced into deep recognition within WIN that its relationship to the natural world is broken. Unless we fix our errant ways, nature will seek revenge. And so, just as the polar bear has become the metaphor for anthropogenic climate change (Weiss), so has anthropogenic climate change itself become a metaphor for this broken relationship. With the realization that human actions are fundamentally altering the course of Earth's evolution, solving the "climate crisis" has become less a question of 'saving the Earth' than of 'saving the species of humankind', and mainstream discourse of climate change has shifted from one of debate to urgent questions of responsibility and problem solving. From this discourse, two interesting frames have emerged from opposite sides of the economic and casual spectrum:

1. From indigenous leaders (Watt-Cloutier), less developed countries represented in the G77, and the United Nations: A clean environment is a universal human right.

2. From a growing swath of political, religious, and academic WIN leaders: Mitigation of climate change is a moral obligation (Gore, Evangelical Climate Initiative, Dobson). Both make these claims, not based on nationality, socio-culture or religious beliefs, but as common members of the human race.

The universalist nature of the two frames - and the national, socio-cultural and religious barriers to translating them into climate change policy - forms the foundation of this paper. Deconstruction of these barriers begins with an evaluation of how cultural difference, identity politics, morality, citizenship, and spiritual and scientific worldviews shape ideas of the political discourse of environmental issues and solutions, presenting a case for: 
1. Replacing "opposition" discourses, which imply false choices (e.g., science or religion, social justice or environmental justice, economic growth or environmental care, science or nature), with "common ground" discourse.

2. Moving the debate on how problems and solutions for climate change are framed from the private sectors' disproportionate influence back into the public forum. The paper then discusses how more humanitarian-based - and effective - environmental policy could be enabled by harnessing three universal quests of human nature: for contact with nature (Wilson), meaning in life (Campbell), and engagement in a larger cause (Csíkszentmihályi).

The paper concludes with recommendations to re-conceptualize the WIN's "pursuit of happiness" away from neo-liberalist notions of wealth accumulation and market expansion towards deeper notions of how true happiness and meaning is universally derived by humankind in order to re-engaging the societies of WIN in Planet Earth, drawing on social movement research on collective responsibility (McDonald, Dobson) and assemblages (Gomezllata). The paper does not argue for a return to fatalism and primitive living, but for progress towards understanding humankind's place in the natural system, respect for the complexity which we can only barely grasp, and justice for all creatures in the natural systems, including humankind.

\section{References}

BBC (2007) All Countries Need to Take Major Steps on Climate Change: Global Poll, 25 September. Campbell, J. (1949) Hero with a Thousand Faces, Third edition. Csíkszentmihályi, M. (1990) Flow: The Psychology of Optimal Experience (New York: Harper Perennial). Dobson, A. (2004) Citizenship and the Environment (New York: University Press USA). Evangelical Climate Initiative (2007) www.evangelicalclimateinitiative.org Gomezllata, E. (2006) Power, Knowledge and Communication in Contemporary Mexico (Tentative PhD dissertation: University of Amsterdam). Gore, A. (2006) An Inconvenient Truth (DVD: Paramount). Hajer, M. (1996) Ecological Modernisation as Cultural Politics in (ed.) Lash, S., Szerszynski, B. and Wynne, B. Risk, Environment \& Modernity: Towards a New Ecology (London: Sage), p. 246 - 268. Hawken, P. (2007) Blessed Unrest: How the Largest Movement in the World Came into Being and Why No One Saw It Coming (New York: Viking Penguin). Hays, S. (1999) Conservation and the Gospel of Efficiency: The Progressive Conservation Movement, 1890-1920. (Pittsburgh: University of Pittsburgh). Marland, G., Boden, T., Andres, R. (2004) Global, Regional, and National CO2 Emissions in Trends: A Compendium of Data on Global Change (Oak Ridge, Tenn.: Carbon Dioxide Information Analysis Center, U.S. Department of Energy). McDonald, K. (2008) After Citizenship? Action and Ethics in Contemporary Social Movements (Oxford: CRESC Conference), 5 September. McKibben, B. (1989) The End of Nature (New York: Random House). Neverla, I. (2007) Storms as Media-Drama: Reconstructing the Public Discourse on Climate-Change (Paris: IAMCR Working Group on Environmental Issues, Science and Risk Communication) 23 July. Sleeth, M. (2006) The Greening of the Faithful (int.) Wildesmith, S. (Wild Side News Radio Show) 19 October. Tilly, C. (2006) Why? (Princeton: Princeton Press). Watt-Cloutier, S. (2003) Former Chair, Inuit Circumpolar Conference Check Against Delivery (Milan: Conference of Parties to the United Nations Framework Convention on Climate Change), 10 December. Weart, S. (2007) The Discovery of Global Warming (online: American Institute of Physics Center for History of Physics) www.aip.org/history/climate/public.htm. Weiss, K. (2008) U.S. Close To Decision On Polar Bears (Los Angeles: Los Angeles Times) 3 February. Wilson, E.O. (1984) Biophilia (Cambridge, MA: Harvard University Press). 